\title{
A Critical Discourse Analysis of ELT Materials in Gender Representation: A Comparison of Summit and Top Notch
}

\author{
Mehran Samadikhah ${ }^{1} \&$ Mohsen Shahrokhi ${ }^{2}$ \\ ${ }^{1}$ Department of English, Faculty of Humanities, Yasuj Branch, Islamic Azad University, Yasuj, Iran \\ ${ }^{2}$ Department of English, Shahreza Branch, Islamic Azad University, Isfahan, Iran \\ Correspondence: Mohsen Shahrokhi (Ph.d.), Department of English, Shahreza Branch, Islamic Azad University, \\ Shahreza, Isfahan, Iran. Tel: 0098-31-5329-2510. E-mail: shahrokhi1651@yahoo.com
}

\author{
Received: October 13, 2014 Accepted: November 15, 2014 Online Published: December 17, 2014 \\ doi:10.5539/elt.v8n1p121 URL: http://dx.doi.org/10.5539/elt.v8n1p121
}

\begin{abstract}
In spite of the crucial importance of textbooks, their increasing development day by day, and their significant effects on saving time, energy, and budgets, only few studies have been done on textbooks evaluation from a critical discourse analysis perspective. This study aimed to analyze and compare the gender representation in Top Notch and Summit series in order to find out if the gender representation is equally balanced in these two textbooks. The study, thus, analyzed the series in terms of nine major aspects of gender: female and male's characters, female and male's pictorial representations, female and male's titles, activities, and firstness of female and male in the mixed gender dialogues. To that end, Fairclough's $(1989,2001)$ models were adopted in order to detect the ideology behind these textbooks. The findings of study indicated that, in most cases, gender representation is more balanced in Top Notch series than in Summit series. The results of this comparative research would also help us gain a better understanding of textbooks currently used in Iranian language institutes.
\end{abstract}

Keywords: materials, textbook evaluation, gender representation, critical discourse analysis (CDA), Iranian context

\section{Introduction}

The importance of textbooks in today's trends of language teaching and learning cannot be denied. Although there might be some opponents of the idea of using published textbooks in ELT classes, the majority of people dealing with education, teaching, and learning assert the saliency of published textbooks in ELT classes. According to Toms (2004), proponents of coursebook argue that it is the most convenient form of presenting materials, it helps to achieve consistency and continuation, and it gives learners a sense of system, cohesion and progress.

As Richards (2001) puts it, textbooks are key components in most language programs. In some situations, he believes, textbooks serve as the basis for much of the language input learners receive and the language practice that occurs in the classroom. He adds that they may provide the basis for the content of the lessons, the balance of skills taught and the kinds of language practice the students take part in. In other situations, they may serve primarily to supplement the teachers' instruction. For learners, the textbook may provide the major source of contact they have with the language apart from input provided by their teacher. In addition, textbooks may also serve as a form of teacher training for inexperienced teachers because they provide ideas on how to plan and teach lessons as well as which formats they can use.

Considering the importance of the textbooks in the field of EFL and the numerous English textbooks which are used in Iran, it seems essential that the books should undergo evaluation to find out their suitability. Textbook evaluation is an educational necessity because it shows whether a textbook is suitable for the particular course and particular learners or not. Weir and Roberts (1994) state two main reasons for evaluating teaching materials. First, it provides evidence "which can inform theoretical disputes about directions to be followed in language teaching or in teacher education" (p. 11). Second, it is a tool to indicate the suitability of particular approaches or techniques under given conditions and whether they meet the claims made for them.

One of the most important issues that have been a concern among discourse analysts and sociolinguistics for a 
long time is the presentation of gender in ELT textbooks; and, therefore, it has attracted the attention of many researchers. This issue affects the student's learning in a positive or negative way. In regard to how age, social class and gender are topically represented in ELT coursebooks, many researchers have focused on different aspects of these materials from a variety of perspectives since, in Cunningsworth's (1995, p. 91) words, "gender differences are not the only area of possible discrimination or unflattering portrayal".

The fact is that what is practiced in the society can be based on some conceptions which may be against expectations of one gender. Such a discursive practice may also be reflected in education systems, in general, and in teaching materials, in particular. English language teaching materials are no exception. In the 1960's, 1970's and 1980's many EFL texts were biased against femininity (Healy, 2009). Furthermore, Gershuny (1997) warns that biased ELT textbooks may perpetuate wrong "gender roles and social values" (p. 150) since textbooks have binary roles. On the one hand, they are supposed to transmit some information and knowledge; on the other hand, they are considered as a manipulative instrument employed by elites. The differences in the speech and behavior of adult males and females may be a consequence of their sexist education in childhood.

This study, therefore, aimed to show how two main ELT textbooks namely Top Notch and Summit series represent male and female in their conversations and activities. This purpose was accomplished through Critical Discourse Analysis (CDA) of ELT materials utilized in the process of teaching and learning. The ultimate goal of the ongoing research was then to find a plausible answer to the question of what the best textbook to choose for the students is and whether gender representation could be a good issue in determining the textbook for Iranian EFL learners with regards to recent findings in the field of ELT and CDA.

According to the problems mentioned and purposes of the study the following questions were the foci in the current study:

1) What are the differences between the representation of male and female characters in the terms of discourse features in the conversations of Top Notch series in comparison to Summit series?

2) Are there any differences in the pictures representation of male and female in Top Notch series in comparison to Summit series?

\section{Review of Literature}

\subsection{The History and Theoretical Diversity of Critical Discourse Analysis}

The CDA as a network of scholars emerged in the early 1990s, following a small symposium in Amsterdam, in January 1991. Through the support of the University of Amsterdam, Teun van Dijk, Norman Fairclough, Gunther Kress, Theo van Leeuwen and Ruth Wodak spent two days together, and had the wonderful opportunity to discuss theories and methods of Discourse Analysis, specifically CDA. The meeting made it possible to confront with each other the very distinct and different approaches, which have, of course, changed significantly since 1991 but remain relevant, in many respects. In this process of group formation, the differences and sameness were laid out: differences with regard to other theories and methodologies in Discourse Analysis (see Renkema, 2004; Titscher et al., 2000; Wetherell et al., 2001; Wodak, 2008) and sameness in a programmatic way, both of which frame the range of theoretical approaches (Wodak, 2004). In the meantime, for example, some of the scholars previously aligned with CDA have chosen other theoretical frameworks and have distanced themselves from CDA (such as Gunther Kress and Ron Scollon); on the other hand, new approaches have been created which frequently find innovative ways of integrating the more traditional theories or of elaborating them.

One of the benefits of CDA is its ability to bring together social and linguistic analyses of discourse, thus integrating analysis at the macro level of social structure with analysis at the micro level of social action. A recent approach to the investigation of the role of language and gender is critical discourse analysis. Fairclough (2001) identified two main purposes in designing the CDA framework of discourse and language, one is more theoretical: "to help correct a widespread underestimation of the significance of language in the production, maintenance, and change of social relations of power". Fairclough's second purpose which is more practical is: "to help increase consciousness of how language contributes to the domination of some people by others, because consciousness is the first step toward emancipation" (Fairclough, 2001, p. 1). Thus, CDA is known as a recent trend in analyzing different components of language. CDA has the capacity to deal with the texts which are being used in new contexts. It is also useful for gaining understandings about the theoretical aspects of education.

\subsection{Practical Studies on EFL Textbooks}

In this part, a couple of studies that have been conducted in the area of the materials evaluation in ELT are reported. These studies are varied in their subjects and aims. As they seem, different frameworks and criteria 
have been used for different purposes, in other words, they are not only evaluative studies. Some studies were comparative, for instance an ESL textbook has been compared to an EFL one.

Azizfar, Koosha, and Lofti (2001) evaluated two series of ELT textbooks used for teaching English language in Iranian high schools from 1970 to the present. In order to evaluate the current textbooks, the researchers employed the Tucker's (1975) textbook evaluation model. The materials used in their study were two locally produced series of English language textbooks used in Iranian high schools and Tucker's (1975) evaluation model. According to findings of this study, there are not considerable differences between GE and PRE series. The major difference lies in the pronunciation criteria in which GE has several serious problems which should have obviously been amended in PRE. The findings of this study also showed that PRE employed the recent improvement in some areas, but not in all the areas. Pre achieves better scores in the grammar and the content criteria. This study finally concludes that these textbooks cannot meet the learners and teachers needs within the Iranian educational system.

Ghorbani (2011) claimed that part of the English language problems in Iran are supposed to arise from the inadequacies in the design of the prescribed English textbooks used at high school levels. His study examined the first grade English textbook used in Iran's senior high schools based on the current research findings in syllabus design, English language teaching, and the specific language teaching situation in Iran to determine the extent to which it conforms to the common universal characteristics of EFL/ESL textbooks. Detailed analysis focused specifically on the use of a checklist extracted from different EFL textbook evaluation checklists corresponding to the local needs. The findings of his study show that only $63 \%$ percent of the book conforms to the universal characteristics of textbooks.

A rich and growing body of studies has also investigated the role of gender in language acquisitions studies. Among all, there are research studies that measured the relationship between gender and language or discourse (Goddard \& Patterson, 2000; Litosseliti \& Sunderland, 2002); the special concerns and issues of immigrant women (Frye, 1999; Goldstein, 1995, 2001; Kouritzin, 2000; Norton, 2000; Rivera, 1999); and women's needs and voices in EFL situations (McMahill, 1997, 2001; Saft \& Ohara, 2004).

Despite the mentioned studies which tried to scrutinize the overall role of gender in society, there are not many studies which have tried to evaluate the textbooks with regard to the gender related issues. With regard to the significance of textbooks in language education, the present study intended to analyze the Top Notch and Summit series with respect to gender representation within the framework of CDA.

\section{Methodology}

\subsection{Selected Framework}

In this study Flairclough's $(1989,2001)$ three dimensional models were adopted and used to analyze gender representation in conversation as well as pictorial representation in Top Notch and Summit series. Thus, two different text book series, Top Notch and Summit series were chosen to know if they are sufficiently gender balanced or if there is a significant imbalance within any series.

\subsection{Participants}

As this research was a comparison of the different text books to find out their ideology, there was no human participant in the study. The data was collected from conversation parts of the two sets of text books under investigation.

\subsection{Materials and Instrument}

Two different series of textbooks were selected for the current study as the materials, the first one was Top Notch and the second one was Summit. As mentioned earlier, the single yet comprehensive instrument of the study in hand was the checklists developed based on Fairclough $(1989,2001)$.

\subsection{Procedures}

Several checklists were first developed in order to examine the explicit features of Top Notch and Summit series regarding gender related concepts which were explained. These checklists were based on Fairclough's (1989, 2001) framework. As Fairclough directed in his framework according to the nature of the materials under evaluation some minor changes was applied, the general format was in accordance with the framework though. In the first part, Flairclough's (2001) three dimensional model was used to analyze gender representation in conversation as well as pictorial representation in Top Notch and Summit series. Extracted data was interpreted in order to conduct the second step of Fairclough's model. As the next step, for analyzing the conversation based on Fairclough (1989), five factors were examined: female and male characters, female and male 
pictorial representation, fitness in the gender dialogue, female and male titles, and activities.

It is worth mentioning here that these checklists, proposed by Fairclough, are developed in a way that they could be worked on by even one rater. Here, in order to enhance the reliability of evaluation, three experts were asked to help the researcher to evaluate the materials. Each rater was provided with a sample of the material and checklists to work on. After the checklists were filled out and the relevant data were gathered, the collected data were coded into computer by means of the Statistical Package for Social Sciences (SPSS) version number 20. The next step was to go through tabulation of data in terms of their significance related to the purposes of the study.

\section{Results}

\subsection{Results of the First Phase of the Study}

The first part includes the results obtained from analyzing the textbooks in terms of three factors namely a) gender representations in conversation parts, b) total relations, and c) male/female subject positions. The results are presented in the following sections.

\subsubsection{Frequency of Gender Representation in Conversation Parts in Top Notch Series}

Table 1 shows the frequency of positions that each gender possesses in these equal relations is almost equally distributed. Each gender almost possesses the frequency of half of these relations which is indicative of approximately equal positions of both genders in the relation dimension in the Top Notch series.

Table 1. Frequency of gender representation in conversation parts in Top Notch series

\begin{tabular}{lllllll}
\hline Equal Relations (X-Y) & $\begin{array}{l}\text { No. of "X" } \\
\text { Incidents }\end{array}$ & $\begin{array}{l}\text { Female } \\
\text { as "X" }\end{array}$ & $\begin{array}{l}\text { Male } \\
\text { as "X" }\end{array}$ & $\begin{array}{l}\text { No. of "Y" } \\
\text { Incidents }\end{array}$ & $\begin{array}{l}\text { Female } \\
\text { as "Y" }\end{array}$ & $\begin{array}{l}\text { Male } \\
\text { as "Y" }\end{array}$ \\
\hline Friend-Friend & 50 & 24 & 26 & 39 & 20 & 19 \\
Student-Student & 8 & 5 & 3 & 8 & 4 & 4 \\
Colleague-Colleague & 11 & 4 & 7 & 11 & 4 & 7 \\
Passenger-Passenger & 2 & 0 & 2 & 2 & 2 & 0 \\
Clerk-Clerk & 1 & 0 & 1 & 1 & 1 & 0 \\
Operator-Operator & 2 & 0 & 2 & 2 & 2 & 0 \\
Neighbor-Neighbor & 2 & 2 & 0 & 2 & 2 & 0 \\
Total & 76 & 35 & 41 & 65 & 35 & 30 \\
\hline
\end{tabular}

\subsubsection{Frequency of Gender Representation in Conversation Parts in Summit Series}

The descriptive data shown in Table 2 indicates that the frequency of positions that each gender possesses in these equal relations is not equally distributed.

Table 2. Frequency of gender representation in conversation parts in Summit series

\begin{tabular}{lllllll}
\hline Equal Relations (X-Y) & $\begin{array}{l}\text { No. of "X" } \\
\text { Incidents }\end{array}$ & $\begin{array}{l}\text { Female } \\
\text { as "X" }\end{array}$ & $\begin{array}{l}\text { Male as } \\
\text { "X" }\end{array}$ & $\begin{array}{l}\text { No. of "Y" } \\
\text { Incidents }\end{array}$ & $\begin{array}{l}\text { Female } \\
\text { as "Y" }\end{array}$ & $\begin{array}{l}\text { Male } \\
\text { as "Y" }\end{array}$ \\
\hline Friend-Friend & 28 & 13 & 15 & 28 & 16 & 12 \\
Student-Student & 11 & 5 & 6 & 11 & 7 & 4 \\
Colleague-Colleague & 7 & 2 & 5 & 7 & 4 & 3 \\
Passenger-Passenger & 3 & 0 & 3 & 3 & 2 & 1 \\
Clerk-Clerk & 0 & 0 & 0 & 0 & 0 & 0 \\
Operator-Operator & 0 & 0 & 0 & 0 & 0 & 0 \\
Neighbor-Neighbor & 2 & 0 & 2 & 2 & 2 & 0 \\
Total & 51 & 20 & 31 & 51 & 31 & 20 \\
\hline
\end{tabular}

Male gender almost possesses the frequency of more than half of these relations which is indicative of approximately more positions of males in the relation dimension in the Summit series. In order to be more specific regarding the claim of difference between these two series, chi-square technique was run to detect the difference, results of which is depicted in Table 3. 
Table 3. Chi-square of gender frequency representation in conversation parts in Top Notch and Summit series

\begin{tabular}{lllllll}
\hline \multirow{2}{*}{ Type of Book } & $\begin{array}{l}\text { Frequency and } \\
\text { percentage of } \\
\text { Female as "X" }\end{array}$ & $\begin{array}{l}\text { Frequency and } \\
\text { percentage of } \\
\text { Male as "X" }\end{array}$ & $\begin{array}{l}\text { Frequency and } \\
\text { percentage of } \\
\text { Female as "Y" }\end{array}$ & $\begin{array}{l}\text { Frequency and } \\
\text { percentage of } \\
\text { Male as "Y" }\end{array}$ & X & Sig. \\
\hline Top Notch series & $35(46.05 \%)$ & $41(53.95 \%)$ & $35(53.85 \%)$ & $30(46.15 \%)$ & 2.392 & 0.126 \\
Summit series & $20(39.22 \%)$ & $31(60.78 \%)$ & $31(60.78 \%)$ & $20(39.22 \%)$ & 5.19 & 0.003 \\
\hline
\end{tabular}

$\mathrm{df}=1, \alpha=0.05(3.84146)$.

Chi-Square test was used to see whether the difference between Top Notch and Summit series in gender representation in conversation parts is significant or not. For the $x^{2}$ test, the number of degrees of freedom is the number of categories minus one. This is $\mathrm{d}=\mathrm{k}-1=2-1=1$ degrees of freedom. For $\alpha=0.05$ and 1 degrees of freedom, the $\mathrm{x}^{2}$ value from the table is 3.84146. The observed value of $\mathrm{x}^{2}$ for Top Notch is 2.392 which is less than its critical value; the $\mathrm{p}$-value is also greater than that of determined level:

Observed $x^{2}=2.392<$ critical $x^{2}=3.84,(0.126>0.05)$

Therefore, there is not a significant difference between Top Notch series in gender representation in conversation parts. The same test for the Summit series shows that Observed $x^{2}=5.19>$ critical $x^{2}=3.84(0.003<0.05)$, thus this is well into the region of rejection of the null hypothesis. Up to now, and with respect to the results obtained from inferential statistics (Chi-Square test) it could be claimed that male gender is favored in conversation parts in Summit series and not in Top Notch series.

\subsubsection{Total Relations in Top Notch Series}

Table 4 illustrates the similarities and differences between the three categorizations of relations. As it is shown in the following table, $43 \%$ of relations belong to female-male relations. In addition, female-female relations have the percentage of $30 \%$ and male-male relations $23 \%$ out of total relations.

Table 4. Total relations in Top Notch series

\begin{tabular}{lll}
\hline Relation & Frequency & Percentage \\
\hline Female-Male & 57 & $\% 43$ \\
Female-Female & 40 & $\% 30$ \\
Male-Male & 31 & $\% 23$ \\
Not specified & 4 & $\% 4$ \\
Total & 132 & $\% 100$ \\
\hline
\end{tabular}

\subsubsection{Total Relations in Summit Series}

Table 5 illustrates the similarities and differences between the three categorizations of relations. As it is shown in the table, $43 \%$ of relations belong to female-male relations which are exactly the same for that of female-male relations of Top Notch series (Table 4). In addition, female-female relations have the percentage of $23 \%$ and male-male relations $29 \%$ out of total relations which differ from that of Top Notch series.

Table 5. Total relations in Summit series

\begin{tabular}{lll}
\hline Relation & Frequency & Percentage \\
\hline Female-Male & 43 & $\% 43$ \\
Female-Female & 23 & $\% 23$ \\
Male-Male & 29 & $\% 29$ \\
Not specified & 5 & $\% 5$ \\
Total & 100 & $\% 100$ \\
\hline
\end{tabular}

A Chi-square was then run to see whether the observed difference in female-female and male-male relations in two series is significant. The result of the Chi-square test is depicted in Table 6. 
Table 6. Chi-square of female - female versus male - male relations frequency in Top Notch and Summit series

\begin{tabular}{lllllll}
\hline Type of Book & $\begin{array}{l}\text { Total No. of } \\
\text { Occurrence }\end{array}$ & $\begin{array}{l}\text { Frequency and } \\
\text { percentage of } \\
\text { Female-Fem } \\
\text { ale Relation }\end{array}$ & $\begin{array}{l}\text { Frequency and } \\
\text { percentage of } \\
\text { Male-Male } \\
\text { Relation }\end{array}$ & Not identified & $\mathrm{X}^{2}$ & Sig \\
\hline Top Notch series & 132 & $40(30 \%)$ & $31(23 \%)$ & 61 & \multirow{2}{*}{1.76} & 0.653 \\
Summit series & 100 & $23(23 \%)$ & $29(29 \%)$ & 48 & & \\
\hline
\end{tabular}

$\mathrm{df}=2 \alpha=0.05(5.9915) \mathrm{p}=0.653$.

According to the statistics depicted in the table 6 , there is a difference in the occurrence of Female-Female and Male - Male Relation in the two series but since the p-value is much more than expected $(0.653>0.05)$, and the observed $X^{2}$ was also less that critical value $(1.76<5.9915)$, it was concluded that the difference was not statistically significant. Thus, the results do not show a change in assigning relations in the mentioned books.

\subsubsection{Female and Male Subject Position in Top Notch Series}

Table 7 displays the male and female subject position in Top Notch series. The subject positions for all the interactions in all conversations in the Top Notch series were investigated in five categories of family, societal, commercial, occupational and other.

Table 7. Female and male subject position in Top Notch series

\begin{tabular}{lllllll}
\hline Gender & Family & Societal & Commercial & Occupational & Other & Total \\
\hline Female & $\% 12$ & $\% 18$ & $\% 20$ & $\% 21$ & $\% 29$ & $\% 100$ \\
Male & $\% 10.5$ & $\% 16.5$ & $\% 20$ & $\% 23$ & $\% 30$ & $\% 100$ \\
\hline
\end{tabular}

As it can be seen in the table above, the category other makes up $29 \%$ and $30 \%$ respectively of total subject positions for females and males, nominating the category as the highest frequent subject postion. It is obvious that the interlocutors in this group do not belong to any other categories and their subject positions are not clearly specified. All positions considered for male and females in categories Formal, Societal, Commercial, and Occupational make up $71 \%$ and $70 \%$ respectively for female and male positions in the conversations and pictorial representations in which they interact. Hence, the subject positions are almost equally distributed between both genders.

\subsubsection{Female and Male Subject Position in Summit Series}

Table 8 displays the male and female subject position in Summit series. The subject positions for all the interactions in all conversations in the Summit series were investigated in five categories of family, societal, commercial, occupational and other. As it can be seen in Table 8, 33\% and 30\% of females and males respectively were identified in the category other, registering it as the highest percentage.

Table 8. Female and male subject position in Summit series

\begin{tabular}{lllllll}
\hline Gender & Family & Societal & Commercial & Occupational & Other & Total \\
\hline Female & $\% 10$ & $\% 16$ & $\% 17$ & $\% 24$ & $\% 33$ & $\% 100$ \\
Male & $\% 14$ & $\% 19$ & $\% 16$ & $\% 21$ & $\% 30$ & $\% 100$ \\
\hline
\end{tabular}

All positions considered for male and females in categories Formal, Societal, Commercial, and Occupational make up $67 \%$ and $70 \%$ respectively for female and male positions. Hence, the subject positions are almost equally distributed between both genders and both genders possess the same subject position in Summit series. Thus, the subject positions for both genders are equally assigned in the two series.

\subsection{Results of Second Phase of the Study}

This part includes the results obtained from analyzing the textbooks in terms of five factors: a) female and male characters, b) female and male's pictorial representation, c) firstness of female and male in the mixed gender dialogues, d) female and male's titles, and e) activities. To this end, the data related to these five factors were collected from the conversations and described. The results of analyzing these dimensions in the order 
mentioned above are as follows:

\subsubsection{Results Obtained Through Analyzing Female and Male Characters in Conversation Part in Top Notch}

As far as the descriptive statistics is concerned, Table 9 shows the supremacy of females over males in Top Notch Fundamental. Generally, 56 cases out of 106 are related to females in forms of proper nouns, pronouns; while, males occupy 50 cases. In fact, this textbook addresses female characters in $53 \%$ of cases, and male characters in 47\%. Table 9 also indicates the supremacy of male over females in Top Notch 1 regarding descriptive statistics. The text book addresses male characters in $58 \%$ and female characters in $42 \%$.

Table 9. Chi-square of male and female frequency characters in conversation parts of Top Notch series

\begin{tabular}{lllllllllllll}
\hline Text Book & Fundamentals & Top Notch 1 & Top Notch 2 & Top Notch 3 & Total & & \\
\hline Gender & F & M & F & M & F & M & F & M & F & M & X $^{2}$ & Sig. \\
Frequency & 56 & 50 & 26 & 36 & 22 & 19 & 32 & 27 & 136 & 132 & 1.295 & 0.382 \\
Percentage & 53 & 47 & 42 & 58 & 54 & 46 & 54 & 46 & 50.7 & 49.3 & & \\
\hline
\end{tabular}
$\mathrm{df}=3, \alpha=0.05(7.8147)$.

Regarding the Top Notch 2, table 9 indicates the supremacy of females over males. The text book addresses female characters $\% 54$ and male characters $46 \%$. According to table, the researcher found the supremacy of female over males in Top Notch 3. The text book addresses female characters $54 \%$ and male characters $46 \%$. Even though the difference seems to be obvious regarding the descriptive statistics, the item at hand needs more exact clarification which will be taken care of in the analysis and interpretation of Chi-square test (see below).

Despite descriptive statistics which demonstrated supremacy of females over males in Top Notch Series, based on the results of Chi-square it was revealed that the difference was not significant. To put it other way, the results when using these sample data are not strong enough to conclude that there is a statistically significant relationship between male and female characters in conversation parts of Top Notch series $(0.382>0.05)$.

The total sum also confirms this fact since the text books addressed female characters about $50.7 \%$ and male characters $49.3 \%$ of the total sum. The Observed $X^{2}$ value (1.295) is also far less than critical $X^{2}$ (7.8147). Thus, it could be concluded that although there seem to be a difference regarding the descriptive statistics, the difference is not meaningful and we can claim that the distribution of both genders is nearly balanced in Top Notch series.

\subsubsection{The Results Obtained from Analyzing Female and Male Characters in Conversation Part in Summit Series}

Table 10 shows the supremacy of males over females. The text book addresses male characters in Summit one $49.2 \%$ and female characters $40.8 \%$. Regarding the Summit 2, again the result shows the supremacy of males over females. The text book addresses male characters $47.8 \%$ and female characters $42.2 \%$. The total sum also indicates the supremacy of males over females. In sum, the text book addresses male characters $48.5 \%$ and female character $41.5 \%$. The results obtained from Chi-square also confirmed that the difference is statistically significant $(0.026<0.05)$. Based on the results, it can be concluded that there is a meaningful bias towards males regarding female and male characters in Summit series.

Table 10. Chi-square of male and female frequency in conversation parts of Summit series

\begin{tabular}{lllllllll}
\hline Text Book & \multicolumn{2}{l}{ Summit 1} & \multicolumn{2}{l}{ Summit 2} & Total & & \\
\hline Gender & F & M & F & M & F & M & X $^{2}$ & Sig. \\
Frequency & 47 & 58 & 41 & 56 & 88 & 114 & 5.735 & 0.026 \\
Percentage & 44.8 & 55.2 & 42.2 & 57.8 & 43.6 & 56.4 & & \\
\hline
\end{tabular}

$\mathrm{df}=1, \alpha=0.05(3.8 \overline{4146)}$.

\subsubsection{Female and Male Pictorial Representation in Top Notch Series}

This part examines pictorial representation in the Series. Table 11 summarizes the pictorial representation in Top Notch series. Table 11 indicates that Top Notch series contain 373 pictures relating to gender, out of which, 190, cases manifest "male characters", and 149 cases manifest the female characters with the supremacy of males. 
Table 11. Frequencies of pictorial presentation in Top Notch series

\begin{tabular}{llllllll}
\hline Pictorial P & Male & Female & Not Identified & Total & $\mathrm{X}^{2}$ & Sig. \\
\hline Fundamentals & 72 & 38 & 4 & 114 & & \\
Top Notch 1 & 46 & 33 & 7 & 86 & & \\
Top Notch 2 & 35 & 37 & 19 & 91 & 10.082 & 0.002 \\
Top Notch 3 & 37 & 41 & 4 & 82 & & \\
Total & 190 & 149 & 34 & 373 & & \\
\hline
\end{tabular}

$\mathrm{df}=3, \alpha=0.05(\overline{7.8147)}$.

Furthermore, 34 cases could not be recognized whether they represented females or males. The results obtained from Chi-square also confirmed that the difference is statistically significant $(0.002<0.05)$. Thus, the results were the bases to claim that there exists bias towards males in Top Notch series as far as the pictorial representation is concerned.

\subsubsection{Female and Male Pictorial Representation in Summit Series}

Table 12 shows that this series contains a sum of 184 pictures relating to gender out of which, 83 cases represent male character and 91 cases represent the female character with the supremacy of female characters which does not seem to be significant. The descriptive statistics could be the criteria here, since the difference is not significant so we can conclude that female and male characters are almost equally balanced in Summit series.

Table 12. Frequencies of pictorial presentation in Summit series

\begin{tabular}{lllll}
\hline Pictorial P & Male & Female & Not identified & Total \\
\hline Summit 1 & 47 & 51 & 3 & 103 \\
Summit 2 & 36 & 40 & 7 & 83 \\
Total & 83 & 91 & 10 & 184 \\
\hline
\end{tabular}

\subsubsection{Firstness in Mixed Gender Dialogues in Top Notch Series}

The results show that 68 out of 129 conversations are dedicated to mixed gender dialogues. Interestingly, this paper revealed some traces of gender bias in favour of male characters; since in $59 \%$ of mixed gender dialogues, it is the men who start the conversations. Table 13 shows the firstness in mixed gender dialogues in Top Notch series.

Table 13. Distribution of both genders in mixed gender dialogues in Top Notch series

\begin{tabular}{llllll}
\hline Top Notch series & No of mixed gender & Male started & Female started & $X^{2}$ & Sig. \\
\hline Fundamentals & 26 & $19(72 \%)$ & $7(28 \%)$ & & \\
Top Notch 1 & 14 & $7(50 \%)$ & $7(50 \%)$ & & \\
Top Notch & 15 & $8(54 \%)$ & $7(46 \%)$ & 8.2305 & 0.015 \\
Top Notch & 13 & $6(46 \%)$ & $7(54 \%)$ & & \\
Total & 68 & $40(59 \%)$ & $28(41 \%)$ & & \\
\hline
\end{tabular}

$\mathrm{df}=3, \alpha=0.05(7.8147)$.

As clearly shown in the table above, regarding the results of Chi-square, the observed difference is also significant $(0.015<0.05)$. Thus, men were initiative in conversations in Top Notch series.

\subsubsection{Firstness in Mixed Gender Dialogues in Summit Series}

Table 14 indicates that 42 out of 79 conversations are dedicated to mixed gender dialogues. Interestingly, this study, again, revealed some traces of gender bias in favour of male characters; since in $59.3 \%$ of mixed gender dialogues, it is the men who start the conversations. As depicted in Table above, regarding the results of Chi-square, in addition to descriptive statistics, the observed difference is again significant $(0.016<0.05)$. Thus, men were initiative in conversations in Summit series as it was also the case with Top Notch series. 
Table 14. Distribution of both genders in mixed gender dialogues in Summit series

\begin{tabular}{llllll}
\hline Summit series & No of Mixed gender & Male started & Female started & $\mathrm{X}^{2}$ & Sig. \\
\hline Summit 1 & 23 & $14(60.8 \%)$ & $9(39.2 \%)$ & & \\
Summit 2 & 19 & $11(57.8 \%)$ & $8(42.2 \%)$ & 4.2643 & 0.016 \\
Total & 42 & $25(59.3 \%)$ & $17(40.7 \%)$ & & \\
\hline
\end{tabular}

$\mathrm{df}=1, \alpha=0.05(3.84146)$.

\subsubsection{Female and Male's Titles in Top Notch Series}

In Top Notch Series, there are so few cases of using the titles of Miss or Ms. In fact, two titles of Mr. and Mrs. are the only titles presented in the conversations of these textbooks with the frequency of 16 and 7 respectively.

Table 15. Frequency and percentage of female and male titles in Top Notch series

\begin{tabular}{llllll}
\hline Titles & Fundamentals & Top Notch 1 & Top Notch 2 & Top Notch 3 & Total \\
\hline Mr. & $10(77 \%)$ & $8(82 \%)$ & $7(58 \%)$ & $8(57 \%)$ & $33(65 \%)$ \\
Mrs. & $4(29 \%)$ & $2(18 \%)$ & $3(25 \%)$ & $4(28.5 \%)$ & $13(25 \%)$ \\
Miss & $0(0 \%)$ & $0(0 \%)$ & $2(42 \%)$ & $2(14 \%)$ & $4(8 \%)$ \\
Ms. & $0(0 \% 0$ & $1(1 \%)$ & $0(0 \%)$ & $0(0 \%)$ & $1(2 \%)$ \\
Total & $14(27.5 \%)$ & $11(21.5 \%)$ & $12(23.5 \%)$ & $14(27.5 \%)$ & $51(100 \%)$ \\
\hline
\end{tabular}

Table 15 shows that Mr. occupied 65\% in Top Notch Series, Mrs.25\%. The Series also contains two other titles, i.e. Miss and Ms. with $.07 \%$ and $0.02 \%$, respectively. As the portion of Mrs. is high compared with Miss and Ms. this point comes into mind that the marital status of women is significant. The supremacy of Mr. to the titles specific to females denotes the important roles inculcated for men.

\subsubsection{Female and Male's Titles in Summit Series}

Table 16 shows that Mr. occupied 65\% in Summit Series, Mrs.36\%. The Series also contains two other titles, i.e. Miss and Ms. with 4\% and $0.0 \%$, respectively. As the portion of Mrs. is high compared with Miss and Ms. this point comes into mind that the marital status of women is significant. The supremacy of Mr. to the titles specific to females denotes the important roles inculcated for men in Summit series as was the case with Top Notch series.

Table 16. Frequency and percentage of female and male titles in Summit series

\begin{tabular}{llll}
\hline Titles & Summit 1 & Summit 2 & Total \\
\hline Mr. & $8(61.8 \%)$ & $7(58 \%)$ & $15(60 \%)$ \\
Mrs. & $5(38.2 \%)$ & $4(33 \%)$ & $9(36 \%)$ \\
Miss & $0(0 \%)$ & $1(9 \%)$ & $1(4 \%)$ \\
Ms. & $0(0 \%)$ & $0(0 \%)$ & $0(0 \%)$ \\
Total & 13 & 12 & 25 \\
\hline
\end{tabular}

\subsubsection{Male and Female Activities in Top Notch Series}

This part represents the activities that both genders are engaged in. These activities are summarized in Table 17. The Table shows that all the activities are monopolized or dominated by males, working, playing, social activities, and studying or going to school are exceptions. It seems that there is a particular pattern governing the activities contributed to each gender.

Table 17 shows the range of activities in Top Notch series. This Table indicates that women have more diverse activities as men in the Top Notch series. Some activities are equally distributed between two genders. 
Table 17. Results of frequency of all activities done by both gender in four types of Top Notch textbooks

\begin{tabular}{|c|c|c|c|c|c|c|c|c|c|c|c|c|}
\hline \multirow{2}{*}{ Activities } & \multicolumn{2}{|c|}{ Fundamentals } & \multicolumn{2}{|c|}{ Top Notch } & \multicolumn{2}{|c|}{ Top Notch 1} & \multicolumn{2}{|c|}{ Top Notch 1} & \multicolumn{2}{|c|}{ Total } & \multirow{2}{*}{$X^{2}$} & \multirow{2}{*}{ Sig. } \\
\hline & $\mathrm{M}$ & $\mathrm{F}$ & $\mathrm{M}$ & $\mathrm{F}$ & $\mathrm{M}$ & $\mathrm{F}$ & $\mathrm{M}$ & $\mathrm{F}$ & $\mathrm{M}$ & $\mathrm{F}$ & & \\
\hline Party & 3 & 2 & 9 & 1 & 7 & 3 & 5 & 4 & 24 & 10 & & \\
\hline Driving & 4 & 0 & 5 & 1 & 5 & 4 & 7 & 5 & 21 & 10 & & \\
\hline shopping & 1 & 3 & 0 & 3 & 3 & 4 & 2 & 1 & 6 & 11 & & \\
\hline Vacation & 3 & 3 & 5 & 5 & 6 & 6 & 3 & 3 & 17 & 17 & & \\
\hline Eating & 0 & 1 & 1 & 2 & 2 & 4 & 4 & 2 & 7 & 9 & & \\
\hline Working & 11 & 15 & 21 & 43 & 17 & 34 & 3 & 7 & 52 & 99 & & \\
\hline Studying & 5 & 2 & 4 & 9 & 7 & 8 & 4 & 5 & 20 & 24 & & \\
\hline Playing & 1 & 7 & 2 & 8 & 4 & 7 & 2 & 3 & 9 & 25 & 28.133 & 0.009 \\
\hline Watching TV & 1 & 3 & 3 & 2 & 4 & 4 & 3 & 4 & 11 & 13 & & \\
\hline Social activities & 0 & 6 & 2 & 1 & 4 & 8 & 5 & 7 & 11 & 22 & & \\
\hline Sport & 3 & 1 & 5 & 2 & 4 & 3 & 4 & 6 & 16 & 12 & & \\
\hline Personal activity & 6 & 7 & 8 & 5 & 6 & 5 & 7 & 4 & 27 & 21 & & \\
\hline traveling & 6 & 1 & 3 & 3 & 5 & 4 & 5 & 5 & 19 & 13 & & \\
\hline House work & 3 & 0 & 9 & 8 & 8 & 2 & 3 & 2 & 23 & 12 & & \\
\hline Total & 41 & 60 & 70 & 94 & 78 & 106 & 56 & 59 & 189 & 260 & & \\
\hline
\end{tabular}

$\mathrm{df}=13, \alpha=0.05(22.362)$.

In effect, there are some activities which are dominated by males for example "making/going to party", "driving", "sport", "personal activities", "traveling", and even "housework"; and some activities which are dominated by females like "working", "playing", "shopping", and "engaging in social activities". Furthermore, there are some activities distributed almost equally between two genders for example, "eating in restaurant", "studying", "going on vocation", or "watching T.V". Up to this point and on the bases of the descriptive statistics, it was made clear that there exists a bias towards gender considering all activities done by both gender in four types of Top Notch text books. To prevent redundancy and wordiness, the results of Chi-square will be presented and catered about in the next part together with that of Summit series.

\subsubsection{Male and Female Activities in Summit Series}

Table 18 indicates that in some activities such as going to party and eating in restaurant male are more active in Summit series but in most activities mentioned in two text books females are more active than males in Summit series. It seems that there is no equality between male and female in Summit series and females have supremacy over males in Summit series. But as it was justified through Table 17, Top Notch series were male oriented with respect to the mentioned activities. Even though these results show that there is evidence to claim that these series are biased towards specific gender, it is difficult at this point to determine whether observed differences are strong enough to come to a plausible conclusion.

Table 18. All activities done by both gender in four types of Summit text books

\begin{tabular}{lllllllll}
\hline \multirow{2}{*}{ Activities } & \multicolumn{7}{l}{ Summit 1} & \multicolumn{3}{l}{ Summit 2} & \multicolumn{3}{l}{ Total } & \multirow{2}{*}{$\mathrm{X}^{2}$} & \multirow{2}{*}{ Sig. } \\
\cline { 2 - 7 } & $\mathrm{M}$ & $\mathrm{F}$ & $\mathrm{M}$ & $\mathrm{F}$ & $\mathrm{M}$ & $\mathrm{F}$ & & \\
\hline Party & 5 & 2 & 4 & 3 & 9 & 5 & & \\
Driving & 2 & 2 & 1 & 3 & 3 & 5 & & \\
shopping & 1 & 3 & 4 & 1 & 5 & 4 & & \\
Vacation & 4 & 4 & 3 & 3 & 7 & 7 & & \\
Eating & 2 & 0 & 1 & 1 & 3 & 1 & 29.047 & 0.012 \\
Working & 9 & 11 & 14 & 16 & 23 & 27 & & \\
Studying & 3 & 3 & 5 & 9 & 8 & 12 & & \\
Playing & 3 & 6 & 4 & 7 & 7 & 13 & & \\
Watching TV & 1 & 2 & 4 & 3 & 5 & 5 & & \\
Social activities & 2 & 7 & 2 & 3 & 4 & 10 & \\
\hline
\end{tabular}




\begin{tabular}{lllllll}
\hline Sport & 2 & 2 & 2 & 3 & 4 & 5 \\
Personal activity & 4 & 8 & 5 & 7 & 9 & 12 \\
traveling & 4 & 3 & 1 & 3 & 5 & 6 \\
House work & 3 & 6 & 2 & 9 & 5 & 15 \\
Total & 45 & 59 & 53 & 71 & 97 & 127 \\
\hline
\end{tabular}

$\mathrm{df}=13, \alpha=0.05(22.362)$.

In order to be sure regarding gained descriptive statistics results, a Pearson Chi-Square test was run on each of these two series to contrast the frequencies of all activities done by male and female. As depicted in the boxes in Tables 17 and 18, p-values were less than the significance level $(0.009 \& 0.012<0.05)$, thus, it was concluded that there are significant differences between the two groups of males and females, considering all activities done in the two series.

Table 19. Total results of the study

\begin{tabular}{llllll}
\hline \multirow{2}{*}{ Dimensions } & \multicolumn{2}{l}{ Equal = E Biased = B } & \multicolumn{2}{l}{ Biased Towards } \\
\cline { 3 - 6 } & & Top Notch & Summit & Male & Female \\
\hline \multirow{2}{*}{ Phase1 } & Gender Representation & E & B & $\sqrt{ }$ & ---- \\
& Total Relations & E & E & --- & --- \\
& Subject Position & E & E & --- & -- \\
& Male/Female Characters & E & B & $\sqrt{ }$ & --- \\
& Pictorial Representations & B & E & $\sqrt{ }$ & --- \\
Phase2 & Firstness in Mixed Gender Dialogues & B & B & $\sqrt{ }$ Both series & --- \\
& Male/Female Titles & B & B & $\sqrt{ }$ Both series & -- \\
& Male/Female in All activities & B & B & $\sqrt{ }$ T/N & $\sqrt{\text { Summit }}$ \\
\hline
\end{tabular}

In other words, the results are strong enough to conclude that there is a statistically significant relationship between gender and all activities done in Top Notch and Summit series. What follow is the summary of the obtained results which is demonstrated in Table 19. What can be gleaned from Table 19 is that male gender is favored in all aspects and dimensions in these two series except for the activities in Summit series.

\section{Discussion}

After conducting different analyses, it was made clear that there is difference between the representation of female and male characters in the terms of discourse in the conversations and pictures of Top-Notch in comparison to Summit series.

Regarding the results gained from the first phase of the experiment and with regards to dimensions namely a) gender relations in conversation parts, b) total relations, and c) male/female subject positions, as well as the second phase and the results obtained from analyzing the textbooks in terms of five factors: a) female and male characters, b) female and male's pictorial representation, c) firstness of female and male in the mixed gender dialogues, d) female and male's titles, and finally e) activities, it was concluded that these two series sure are biased towards specific gender. According to descriptive and inferential statistics gained in the results, male gender, being favored, was presented in all aspects and dimensions in the two series except for that of activities in Summit series. Based on the findings of the study, it is now clear that representation of gender is not out of prejudice since the presentation of men in Summit series was confirmed. The representation of gender in Top Notch series was equal and not biased towards a specific gender.

Regarding the second question of the study and with respect to the pictorial representation, the results confirmed the supremacy of male over female in Top Notch series and the supremacy of females over males in Summit series. What seem to be of utmost importance to be mentioned here is that the answers already given to the questions of the study are not demonstrative of the whole study and since the study in hand possessed different aspects with regard to dimensions of the problem the answers should not interpreted individually and without addressing other constituents. Any interpretations should be carefully grounded with respect to the study as a whole. The results of the study then can be briefly reiterated as follows:

The findings show that gender is represented somewhat differently in these two series with respect to different 
tasks assigned to the specific gender. In effect, in most gender related activities and with regards to discourse dimensions it is the women who pay the price of this inequality and prejudices in Top Notch and Summit series. The tragedy, although with minor exceptions, happened throughout the journey to the two basic and most ubiquitous mentioned textbook series for time being in our country. Accordingly, this study supports the findings of previous experimental investigations such as Farooq (1999), Sano et al. (2001), Stockdale (2006), Paivandi (2008), as well as Johanson (2009) and Esmaili (2011).

As critical discourse analysis aims at revealing the power dominance that might be imposed through disourse, including texts and pictures, this study reveals that traces of power imbalance-the dominant presentation of males- are available in textbooks. It follows that the critical discourse analysis of English textbooks that are going to be written by Iranian authors in the future can be of great importance. Iran as a Muslem country should follow principles of equality among human beings; the principle includes the avoidance of gender representation in textbooks. Therefore, critical discourse analysis of the materials before using them as a textbook provides feedbacks with authors to avoide any imbalance in gender representation in Iranian context.

\section{Conclusion}

The findings revealed that both series, Top Notch and Summit did not have a neutral perspective toward gender representation even pictorially. It means that both genders have not been behaved toward equally even in terms of picture representation. It seems that Top Notch series consciously presents both genders in such a way by which stereotypical norms are ingrained into learners. It can also be viewed that in Summit series males usually have supremacy over females in conversations and pictorial parts. Summit series address the male character more than female character, so male and female characters are not equally distributed in Summit series. Regarding the male and female characters in Top Notch series, the difference is not significant and characters are equally distributed, though. To sum up, the obtained results indicate that, in most cases, gender representation is more balanced in Top Notch series than in Summit series.

The present research can be followed up by researchers as a framework for further studies. Textbooks are among the areas in the field of education process that largely interest and attract the public. Thus, it could be a very large potential for both teachers and students and textbook providers to use those opportunities. For further studies, it is suggested that, the same studies with more and different textbooks are needed to get better and more reliable results.

\section{References}

Ansari, H., \& Babaii, E. (2002). Universal characteristics of EFL/ESL textbooks: A step towards systematic textbook evaluation. The Internet TESL Journal, 8(2).

Ansari, H., \& Babaii, E. (2003). Evaluation of learning objectives in Iranian high-school and pre-university English textbooks using Bloom's taxonomy. TESL EJ (Electronic Journal), 5(1), 5-31.

Bahman, M., \& Rahimi, A. (2010). Gender representation in EFL materials: An analysis of English textbooks of Iranian high schools. Social and Behavioral Sciences, 9, 273-277. http://dx.doi.org/10.1016/j.sbspro.2010. 12.149

Cameron, D. (2001). Working with Spoken Discourse. London: Sage.

Cameron, D., \& Kulick, D. (2003). Language and Sexuality. Cambridge: CUP.

Coles, G. (1977). Dick and Jane grow up: Ideology in adult basic education readers. Urban Education, 12, 37.

Esmaili, F. (2011). A comparative study on gender representation in Iranian High School English textbooks and American Headway series: A critical discourse analysis perspective (Unpublished Master thesis). University of Arak, Arak, Iran.

Fairclough, N. (1989). Language and power. London: Longman.

Fairclough, N. (2001). Language and power (2nd ed.). Harlow: Pearson Education.

Fairclough, N., \& Wodak, R. (1997). Critical discourse analysis. In T. A. Van Dijk (Ed.), Discourse studies: A multidisciplinary introduction: Discourse as social interaction (Vol. 2, pp. 258-284). London: Sage Publication.

Fowler, R. (2002). On Critical linguistics. In M. Toolan (Ed.), Critical discourse analysis: Critical concepts in linguistics (Vol. 1, pp. 346-357). London and New York: Routledge.

Goddard, A., \& Patterson, L. M. (2000). Language and gender. London: Routledge. 
Jahangard, A. (2007). The evaluation of the EFL materials taught at Iranian public high schools. Karen's Linguistics Issues. Retrieved October, 2013, from http://www3.telus.net/linguisticsissues/bymonth.html

Kobia, J. M. (2009). Femininity and masculinity in English primary school textbooks in Kenya. Retrieved March 12, 2010, from http://www.educ.utas.edu.au/users/tle/JOURNAL/issues/2009/28-6.pdf

Kulm, G., Roseman, J., \& Treistman, M. (1999). Benchmarks-Based Approach to Textbook Evaluation. Science Books \& Films, 35(4-A).

Litosseliti, L. (2006). Gender and Language: Theory and Practice. London: Hodder Arnold.

Littlejohn, A. (1998). The analysis of Language teaching materials: Inside the Trojan horse. In B. Tomlinson (Ed.), Materials development in Language teaching (pp. 190-216). Cambridge: Cambridge University Press.

Litz, A. R. D. (n.d.). Textbook evaluation and elt management: A South Korean case study. Asian EFL journal. Retrived from http://www.asian-efl-journal.com/Litz_thesis.pdf

Luke, A. (1997). The Material Effects of the Word: Apologies, 'stolen children' and public discourse. Discourse: Studies in the Cultural Politics of Education, 18(3), 343-368.

Luke, A. (2002). Beyond Science and Ideology Critique: Developments in critical discourse analysis. Annual Review of Applied Linguistics, 22, 96-110. http://dx.doi.org/10.1017/S0267190502000053

Martin, R. (1992). English Text: System and Structure. Amsterdam: John Benjamins.

Mineshima, M. (2008). Gender representations in an EFL textbook. Retrieved March 14, 2013, from http://www.niit.ac.jp/lib/contents/kiyo/genko/13/14_MINESHIMA.pdf

Nazeri, M. S. (2010). Gender positioning in ELT: Critical discourse analysis of a series of internationally and locally produced textbooks (Unpublished Master thesis). University of Kashan, Kashan, Iran.

Paivandi, S. (2008). Discrimination and intolerance in Iran's textbooks. Retrieved March, 2010, from http://www.freedomhouse.org/uploads/press_release/IranTextbookAnalysis_FINAL.pdf

Patterson, A. (1997). Critical Discourse Analysis: A condition of doubt. Discourse: Studies in the Cultural Politics of Education, 18(3), 425-435.

Pennycook, A. (1994). Incommensurable Discourses? Applied Linguistics, 15(2), 115-138.

Pennycook, A. (2001). Critical Applied Linguistics: A critical introduction. London, UK: Lawrence Erlbaum Associates.

Rahimi, A., \& Sahragard, R. (2007). Critical discourse analysis. Tehran: Jungle Publications.

Richards, J. C. (2001). The role of textbooks in a language program. Retrieved October 12, 2004, from $\mathrm{http}: / /$ www.professorjackrichards.com/pdfs/role-of-textbooks

Tahriri, A., \& Moradpour, P. (2012). Gender representation in 'Top-Notch' series: A critical discourse analysis perspective (Unpublished Master thesis). University of Guilan, Iran.

Tomlinson, B. (1998). Materials development in Language teaching. Cambridge: Cambridge University Press.

Tomlinson, B. (2001). Materials development. In R. Carter, \& Nunan (Eds.), The Cambridge guide to teaching English to speakers of other languages (pp. 66-71). Cambridge: Cambridge University press.

\section{Copyrights}

Copyright for this article is retained by the author(s), with first publication rights granted to the journal.

This is an open-access article distributed under the terms and conditions of the Creative Commons Attribution license (http://creativecommons.org/licenses/by/3.0/). 